\title{
HUBUNGAN DUKUNGAN KELUARGA DENGAN KEPATUHAN DIET ASAM URAT PADA LANSIA DI POSYANDU LANSIA WILAYAH KERJA PUSKESMAS WONOKROMO SURABAYA
}

\section{The Relationship Of Family Support With Urine Acid's Diet Compliance In Elderly At Posyandu Lansia Healt Care Center Wonokromo Surabaya}

\author{
M. Didit Sutiono, Nety Mawarda Hatmanti \\ Program Studi S1 Keperawatan \\ Universitas Nahdlatul Ulama Surabaya \\ Ditsu.JR@gmail.com
}

\begin{abstract}
Abstrak
Peningkatan kadar asam urat dalam darah atau hiperurisemia merupakan salah satu prediktor kuat terhadap kematian karena kerusakan kardiovaskuler. Berdasarkan hasil studi pendahuluan di Posyandu lansia wilayah kerja Puskesmas Wonokromo Surabaya didapatkan 23,5\%. Tujuan penelitian ini mengetahui hubungan dukungan keluarga dengan kepatuhan diet asam urat pada lansia di wilayah kerja Puskesmas Wonokromo Surabya. Desain penelitian ini adalah analitik dengan Cross Sectional. Populasi 47 responden dan besar sampel 42 responden. Menggunakan cara non probability sampling dengan teknik purposive sampling. Pengelolaan data menggunakan kuisioner, wawancara. Analisis menggunakan uji statistik Fisher $\alpha=0,05$. Hasil penelitian membuktikan bahwa penderita asam urat sebagian besar $(73,8 \%)$ memiliki dukungan keluarga yang baik, sebagian besar (64,3\%)patuh terhadap diet asam urat. Hasil analisis membuktikan bahwa terdapat hubungan dukungan keluarga dengan kepatuhan diet asam urat $(\rho=0,008)$. Simpulan penelitian ini adalah semakin baik dukungan keluarga kepada penderita asam urat maka semakin patuh menjalani diet asam urat.
\end{abstract}

Kata Kunci : Dukungan keluarga, kepatuhan diet

\begin{abstract}
Increased levels of uric acid in the blood or hyperuricemia is also a strong predictor of death due to cardiovascular damage. Based on the results of a preliminary study at the Posyandu for the elderly, the Wonokromo Surabaya Public Health Center work area was $23.5 \%$. The purpose of this study was to determine the relationship of family support with uric acid diet adherence in the elderly in the working area of Wonokromo Surabya Health Center. The design of this study is analytic with the Cross Sectional approach. The population was 47 patients with uric acid. Sample size of 42 respondents. Using non probability sampling with purposive sampling technique. Data processing using sheets of questionnaires, data analysis using Fisher statistic test $\alpha=$ 0.05. The results showed that of the 42 gout patients most (73.8\%) had good family support, most (64.3\%) obeyed the gout diet. The results of the analysis prove that there is a relationship of family support with compliance with uric acid diet $\rho=0.008$. The conclusion of this study is the better family support for gout sufferers, the more obedient to undergo a gout diet.
\end{abstract}

Key words: Family support, diet obedience.

\section{PENDAHULUAN}

Penyakit degeneratif yang berkembang pesat saat ini salah satunya yaitu asam urat. Penyakit ini tidak tergolong penyakit yang mematikan, penyakit asam urat merupakan penyakit yang sangat mengganggu dan berbahaya. Nyeri yang ditimbulkan penyakit ini dapat mengganggu aktivitas penderitanya. Masyarakat kini beredar mitos bahwa nyeri sendi berarti asam urat. Pengertian ini perlu diluruskan karena tidak semua keluhan dari nyeri sendi disebabkan oleh asam urat. Pengertian yang salah ini diperparah oleh iklan jamu atau obat tradisional. Untuk memastikannya perlu pemeriksaan di laboratotium. Faktor-faktor yang mempengaruhi penyakit ini adalah diet berat badan dan gaya hidup (Paulina, Hendra, Vendri K. 2016). 
Penyakit asam urat sangat erat kaitannya dengan pola makan. Umumnya karena pola makan yang tidak seimbang (jumlah asupan protein sangat tinggi). Namun, bukan berarti penderita asam urat tidak boleh mengonsumsi makanan yang mengandung protein. Hanya saja jumlahnya yang harus dibatasi terutama bagi lansia. Banyaknya lansia yang tidak mempedulikan tentang kesehatannya terutama pada hal makanan dan juga tidak adanya dukungan dari keluarga dalam menyediakan menu sehari-hari. Peningkatan kadar asam urat dalam darah atau hiperurisemia menurut suatu penelitian juga merupakan salah satu prediktor kuat terhadap kematian karena kerusakan kardiovaskuler (Andry, Saryono, Arief 2009).

Secara global telah diprediksi bahwa populasi lansia akan terus mengalami peningkatan. Menurut Survei Ekonomi Nasional (Susenas) Tahun 2008, 2009, 2012, Badan Pusat Statistik Republik Indonesia menyatakan presentase penduduk lanjut usia (lansia) telah mencapai $8,55 \%, 8,3 \%$, dan $7 \%$ dari keseluruhan penduduk. Seiring meningkatnya populasi lansia, pemerintah perlu merumuskan kebijakan dan program yang ditujukan untuk kesejahteraan lansia sendiri. Masalah umum yang dialami oleh lansia adalah rentannya terhadap berbagai penyakit degeneratif yang menyebabkan terjadinya penurunan daya tahan tubuh. Selain itu, keluhan kesehatan yang paling tinggi $(32,99 \%)$ adalah jenis keluhan yang merupakan efek dari penyakit kronis seperti asam urat, darah tinggi, darah rendah dan diabetes (Kemenkes RI, 2013).

Di Indonesia tahun 2009, menunjukkan angka kejadian hiperurisemia di masyarakat antara 2,3-17,6\%, sedangkan kejadian penyakit asam urat antara 0,16- 1,36\%. Pada studi hiperurisemia di rumah sakit ditemukan angka prevalensi yang lebih tinggi antara 17-28\% karena pengaruh penyakit dan obat-obatan yang diminum penderita. Daerah Jawa Timur ditemukan prevalensi hiperurisemia sebesar $24,3 \%$ pada laki-laki dan $11,7 \%$ pada perempuan (Ayuning Dewi. F, 2014). Berdasarkan hasil studi pendahuluan di Posyandu lansia wilayah kerja Puskesmas Wonokromo Surabaya yang dilakukan kepada
200 lansia dan didapatkan $47(23,5 \%)$ orang menderita asam urat.

Keluarga adalah dua atau lebih dari dua individu yang tergabung karena hubungan darah, hubungan perkawinan atau pengangkatan dan mereka hidup dalam suatu rumah tangga, berinteraksi satu sama lain dan di dalam perannya masing-masing menciptakan serta mempertahankan kebudayaan. Sesuai dengan fungsi pemeliharaan kesehatan, keluarga mempunyai tugas dibidang kesehatan yang perlu dipahami dan dilakukan. Dukungan sosial keluarga adalah sebuah proses yang terjadi sepanjang masa kehidupan, sifat dan jenis dukungan sosial keluarga berbeda-beda dalam berbagai tahap siklus kehidupan.

Hasil penelitian didapatkan dukungan keluarga yang dimiliki adalah baik, dukungan keluarga ini dapat berasal dari hubungan darah, hubungan perkawinan atau pengangkatan, hal ini disebabkan oleh sumber dukungan keluarga yang ada. Sumber dukungan yang ada dapat dilakukan oleh keluarga dengan cara mengenal adanya gangguan kesehatan sedini mungkin seperti pada saat anggota keluarga yang menderita penyakit asam urat mengalami keluhan nyeri pada sendi. Disamping itu diet dianjurkan pada orang yang terkena asam urat khusunya lansia lebih diutamakan, karena beberapa penyakit datangnya dari faktor makanan. Diet yang paling utama pada orang yang terkena asam urat yaitu rendah purin, yaitu dengan cara menghindari atau membatasi jenis-jenis makanan yang tinggi purin JASBUKET (Jerohan, Sardencis, Burung, Kaldu, Kacang, Emping, dan Tape). Karena asam urat lebih mudah larut dalam urine yang alkalis, diet rendah purin harus mengandung lebih banyak hidratarang dan lebih sedikit lemak dengan jumlah cairan yang memadai untuk membantu pengeluaran kelebihan asam urat. Kandungan lemak yang tinggi dalam makanan akan menimbulkan asidosis (karena pembentukan keton bodies yang terdiri atas asam asetoasetat, asam $\beta$-hidrosibuktirat dan aseton) yang membuat urine menjadi lebih asam sehingga menyulitkan ekskresi asam urat (Alvin Aaltje. E, Widhi, 2016).

Untuk menurunkan resiko terjadinya peningkatan kadar asam urat dalam darah maupun tumpukan asam urat di persendian, 
perlu dilakukan modifikasi diet. Modifikasi diet yang dimaksud antara lain dengan membatasi makanan yang mengandung purin dan meningkatkan asupan cairan dan buahbuahan. Upaya yang dapat dilakukan sebagai tenaga kesehatan dalam mengontrol kadar asam urat adalah dengan membatasi asupan purin atau mengkonsumsi makanan rendah purin, lebih banyak mengkonsumsi karbohidrat, mengurangi konsumsi lemak, meningkatkan asupan cairan, dan tidak mengkonsumsi minuman beralkohol (Alvin Aaltje. E, Widhi, 2016).

Berdasarkan uraian diatas peneliti tertarik mengambil penelitian tentang hubungan antara dukungan keluarga dengan kepatuhan diet asam urat di Puskesmas Wonokromo.

\section{METODE}

Desain penelitian yang yang digunakan adalah analitik dengan pendekatan crossectional,yaitu penelitian dimana variabel independen penelitian ini adalah dukungan keluarga dan variabel dependen yaitu kepatuhan diet asam urat. Populasi pada penelitian ini adalah 47 responden. Besar sampel penelitian yaitu 42 responden yang diambil secara non probability sampling dengan teknik purposive sampling.

Data dianalisis dengan menggunakan uji statistik uji Fisher dengan kemaknaan $\alpha=0,05$ dengan bantuan SPSS bila didapatkan $\rho$ $<\alpha$ maka $\mathrm{H}_{0}$ ditolak artinya ada hubungan dukungan keluarga dengan kepatuhan diet asam urat pada lansia di Posyandu lansia wilayah kerja Puskesmas Wonokromo Surabaya.

\section{HASIL DAN PEMBAHASAN}

1. Hasil Penelitan

a. Data Umum

Data umum menguraikan responden meliputi umur dan pendidikan terakhir di Puskesmas wilayah kerja Wonokromo Surabaya.

1) Karakteristik responden berdasarkan umur.

Hasil penelitian mengenai karakteristik responden berdasarkan umur menurut WHO (2015) umur lansia dibagi menjadi tiga periode, yaitu: lanjut usia atau erderly (60-74 tahun), lanjut usia tua atau old (75-90) dan usia sangat tua atau very old $(>90)$

Tabel 5.1 Distibusi frekuensi responden berdasarkan umur di Posyandu Lansia wilayah kerja PuskesmasWonokromo Surabaya tahun 2018.

\begin{tabular}{cccc}
\hline No. & Umur (tahun) & Frekuensi & $\begin{array}{c}\text { Persentase } \\
(\%)\end{array}$ \\
\hline 1. & $\begin{array}{c}\text { Lanjut usia } \\
(60-74)\end{array}$ & 34 & 81 \\
2. & $\begin{array}{c}\text { Lanjut usia } \\
\text { tua (75-90) }\end{array}$ & 8 & 19 \\
3. & $\begin{array}{c}\text { Usia sangat } \\
\text { tua (>90) }\end{array}$ & 0 & 0 \\
\hline & Total & 42 & 100 \\
\hline
\end{tabular}

Sumber: Data Primer, Juli 2018

Tabel 5.1 menunjukkan bahwa dari 42 responden terdapat hampir seluruhnya $(81 \%)$ termasuk lanjut usia (60-74 tahun).

2) Karakteristik responden berdasarkan pendidikan terakhir.

Hasil penelitian mengenai karakteristik pendidikan terkhir menurut Permendikbud No. 3 tahun 2013jenjang pendidikan dibagi 3 : Dasar (SD-SMP), Menengah (SMA), dan Tinggi (Perguruan Tinggi).

Tabel 5.2 Distribusi frekuensi responden berdasarkan tingkat pendidikan di Posyandu lansia wilayah kerja Puskesmas Wonokromo Surabaya tahun 2018

\begin{tabular}{cccc}
\hline No. & Pendidikan & Frekuensi & $\begin{array}{c}\text { Persentase } \\
(\%)\end{array}$ \\
\hline 1. & $\begin{array}{c}\text { Tinggi } \\
\text { (perguruan } \\
\text { tinggi) }\end{array}$ & 2 & 4,8 \\
2. & $\begin{array}{c}\text { Menengah } \\
\text { (SMA } \\
\text { sederajat) }\end{array}$ & 14 & 33,3 \\
3. & $\begin{array}{c}\text { Dasar (SD- } \\
\text { SMP } \\
\text { sederajat) }\end{array}$ & 26 & 61,9 \\
\hline & & 100
\end{tabular}

Sumber: Data Primer, Juli 2018

Tabel 5.2 menunjukkan bahwa dari 42 responden terdapat sebagian besar $(61,9 \%)$ berpendidikan dasar. 
b. Data Khusus

1) Dukungan Keluarga

Data khusus berisi karakteristik responden yang meliputi tentang hubungan dukungan keluarga. Dari hasil pengumpulan data pada 42 responden didapakan sebagai berikut.

Tabel 5.3 Distribusi frekuensi responden berdasarkan dukungan keluarga di Posyandu lansia wilayah kerja Puskesmas Wonokromo tahun 2018

\begin{tabular}{cccc}
\hline No. & $\begin{array}{c}\text { Dukungan } \\
\text { Keluarga }\end{array}$ & Frekuensi & $\begin{array}{c}\text { Persentase } \\
(\%)\end{array}$ \\
\hline 1. & Baik & 31 & 73,8 \\
2. & $\begin{array}{c}\text { Kurang } \\
\text { baik }\end{array}$ & 11 & 26,2 \\
\hline & Total & 42 & 100 \\
\hline
\end{tabular}

Sumber: Data Primer, Juli 2018

2) Kepatuhan diet asam urat

Karakteristik responden berdasarkan kepatuhan diet asam urat di Posyandu lansia wilayah kerja Puskesmas Wonokromo Surabaya terdiri dari patuh dan tidak patuh yang dapat dilihat pada tabel 5.4 sebagai berikut:

Tabel 5.4 Distribusi frekuensi responden berdasarkan kepatuhan diet asam urat di Posyandu lansia wilayah kerja Puskesmas Wonokromo Surabaya tahun 2018

\begin{tabular}{lccc}
\hline No. & $\begin{array}{c}\text { Kepatuhan } \\
\text { Diet Asam } \\
\text { Urat }\end{array}$ & Frekuensi & $\begin{array}{c}\text { Persentase } \\
(\%)\end{array}$ \\
\hline 1. & Patuh & 27 & 64,3 \\
2. & Tidak patuh & 15 & 35,7 \\
\hline & Total & 42 & 100 \\
\hline
\end{tabular}

Sumber: Data Primer, Juli 2018

Besarkan tabel 5.4 diatas menunjukkan bahwa dari 42 responden sebagian besar $64,3 \%$ patuh terhadap diet asam urat.

3) Hubungan dukungan keluarga dengan kepatuhan diet asam urat pada lansia di posyandu lansia wilayah kerja Puskesmas Wonokromo Surabaya.
Tabel 5.5 Tabulasi silang Hubungan dukungan keluarga dengan kepatuhan diet asam urat pada lansia di Posyandu lansia wilayah kerja Puskesmas Wonokromo Surabaya tahun 2018.

\begin{tabular}{lccccccc}
\hline \multirow{2}{*}{$\begin{array}{c}\text { Dukunga } \\
\mathrm{n}\end{array}$} & \multicolumn{4}{c}{$\begin{array}{c}\text { Kepatuhan diet } \\
\text { asam urat }\end{array}$} & Total & $\mathrm{P}$ \\
\cline { 2 - 5 } Keluarga & Patuh & $\begin{array}{c}\text { Tidak } \\
\text { patuh }\end{array}$ & & & \\
\hline & $\mathrm{N}$ & $\%$ & $\mathrm{~N}$ & $\%$ & $\mathrm{~N}$ & $\%$ & \\
\hline Kurang & 3 & 7,1 & 8 & 19, & 1 & 26, & \\
Baik & & & & 0 & 1 & 2 & \\
& & & & & & & \\
Baik & 2 & 57, & 7 & 16, & 3 & 73, & 0.00 \\
& 4 & 1 & & 7 & 1 & 8 & 8
\end{tabular}

\begin{tabular}{ccccccc}
\hline Jumlah & 2 & 64, & 1 & 35, & 4 & 100 \\
& 7 & 2 & 5 & 7 & 2 &
\end{tabular}

Berdasarkan tabel 5.5 diatas menunjukkan bahwa dari 42 responden sebesar 31 responden yang memiliki dukungan keluarga yang baik, sebagian besar $(57,1 \%)$ patuh melakukan diet asam urat dan dari 11 responden yang memiliki dukungan keluarga tidak baik, sebagian kecil $(7,1 \%)$ tidak patuh melakukan diet asam urat.

\section{PEMBAHASAN}

1. Dukungan keluaga

Berdasarkan tabel 5.5 menunjukkan bahwa terdapat sebagian besar $(73,8 \%)$ memiliki dukungan keluarga yang baik. Dukungan keluarga yang diberikan adalah dukungan informasional, dukungan instrumental, dukungan penilaian. Akan tetapi pada dukungan emosional didapatkan hasil 46\% dukungan yang diberikan masih kurang karena keluarga hanya memberikan dukungan berupa informasi. selain itu dukungan emosional juga penting karena biasanya pada lansia merasa bahwa dirinya sudah putus asa terhadap penyakitnya.

Menurut peneliti dukungan keluarga merupakan bagian dari penderita yang paling 
dekat dan tidak dapat dipisahkan. Penderita akan merasa senang dan tentram apabila mendapat perhatian dan dukungan dari keluarganya, karena dengan dukungan tersebut akan menimbulkan kepercayaan dirinya untuk menghadapi atau mengelola penyakitnya dengan baik, serta penderita mau mengikuti saran-saran yang diberikan oleh keluarga untuk penunjang pengelolaan penyakitnya.

Menurut teori Noorkasiani dan Tamher (2009) menjelaskan bahwa Dukungan keluarga yang didapatkan oleh responden berupa dukungan secara instrumental, informasional, penilaian, maupun emosional. Dukungan keluarga yang baik dapat mencakup dukungan informasional, instrumental, penilaian dan emosional.

Berdasarkan tabel 5.1 menunjukkan bahwa terdapat hampir seluruhnya (81\%) termasuk usia Lansia antara 60-74 tahun. Menurut peneliti pada usia menua tidak dapat dipungkiri akan terjadi beberapa penurunan fungsi, baik fisik, psikologis, maupun sosial sehingga dapat mempengaruhi kesehatan. Penurunan fungsi tubuh menjadikan terhambatnya proses pengobatan yang dilakukan pihak keluarga. Sehingga segala sesuatu yang diberikan dan di informasikan kepada lansia kurang dapat diterima dengan baik.

Menurut teori Nugroho (2008) bahwa proses penuaan, seseorang dapat mengalami berbagai perubahan. Masa ini biasanya dihadapkan pada penurunan fungsi tubuh dan meningkatnya sensitifitas emosional, seperti sedih, kecewa, rasa putus asa dan harga diri rendah. Selanjutnya dengan adanya penurunan fungsi tersebut biasanya merasa dirinya sudah tidak berguna lagi.

Berdasarkan tabel 5.2 menunjukkan terdapat sebagian besar $(61,9 \%)$ berpendidikan dasar (SD-SMP). Pendidikan berpengaruh terhadap dukungan keluarga karena pendidikan akan membentuk cara berfikir seseorang untuk memotifasi anggota keluarga yang menderita asam urat. Menurut peneliti keluarga dengan penderita asam urat sudah berupaya dalam menjelaskan masalah kesehatan yang didapatkan dari pihak pelayanan kesehatan, tetapi keluarga masih bingung dalam menjelaskannya. Penderita asam urat di posyandu lansia sebagian besar berpendidikan dasar. Tingkat pendidikan yang rendah mengakibatkan kurangnya pemahaman yang diberikan oleh keluarga, serta budaya yang sudah ditanam sejak dahulu mengakibatkan penderita asam urat sudah merasa puas dan benar.

Pendidikan yang rendah menyebabkan seseorang sulit menerima dan menyerap informasi sedangkan pendidikan lebih tinggi mempengaruhi pola pikir seseorang yang berdampak pada perilaku yang baik. Menurut teori Notoadmojo (2007) pendidikan seseorang terhadap adanya dukungan terbentuk oleh variabel intelektual yang terdiri dari pengetahuan, latar belakang pendidikan dan pengalaman masa lalu

2. Kepatuhan diet asam urat

Hasil tabel 5.6 menunjukkan bahwa dari 42 responden terdapat sebagian besar $(64,3 \%)$ patuh terhadap diet asam urat. Secara teori, Kepatuhan adalah istilah yang dipakai untuk menjelaskan ketaatan atau pasrah pada tujuan yang telah ditentukan. Kepatuhan dari program kesehatan merupakan perilaku yang dapat diobservasi dan dengan begitu dapat langsung diukur. Seperti yang dikutip oleh Andreas (2008), bahwa faktor-faktor yang mempengaruhi kepatuhan pasien terhadap terapi yaitu: motivasi diri, persepsi, dukungan keluarga, kepercayaan diri, dukungan dari petugas kesehatan. Hasil penelitian didapatkan kepatuhan diet yang dilakukan pasien adalah patuh.

Salah satu penatalaksanaan bagi penderita asam urat adalah minum obat asam urat akan tetapi hal tersebut tidak lepas dari kepatuhan diet asam urat dari penderita itu sendiri. Diet asam urat bertujuan untuk mengurangi makanan yang kaya akan kandungan purin seperti jeroan, daun melinjo, bayam, sarden, kangkung. Diet asam urat merupakan salah satu metode pengendalian asam urat secara alami, jika dibandingkan dengan obat penurun asam urat yang dapat menumbulkan beberapa efek samping yang terjadi (Noviyanti, 2015).

Pengaturan pola makan dan perubahan gaya hidup termasuk penurunan berat badan, pembatasan minuman alkohol, makanan tinggi purin, dan pengawasan hiperlipidemia dan hipertensi dapat menurunkan kadar serum asam 
urat walau tanpa terapi obat-obatan. Seperti yang dikutip (Kurnia Dewi, 2009) "berkonsultasilah" dengan dokter anda tentang rencana pengobatan yang akan ia lakukan secara lengkap. Hindari penggunaan "jamu" kemasan yang tidak jelas, karena telah banyak bukti kecurangan produsen jamu yang justru merugikan konsumen.

Menurut peneliti Penderita yang mempunyai penyakit asam urat yang lama akan mengalami kebosanan dalam melakukan diet, dengan demikian keluarga sangat berperan penting untuk memotivasi anggota keluarganya yang sedang sakit. Dukungan tersebut dapat berbentuk dengan pemberian informasiinformasi yang dibutuhkan oleh penderita yaitu berupa pemaparan tentang makanan-makanan yang perlu dihindari penderita asam urat.

3. Hubungan dukungan keluarga dengan kepatuhan diet asam urat pada lansia di Posyandu lansia

Tabel 5.6 menunjukkan bahwa dari 42 responden sebesar 31 responden yang memiliki dukungan keluarga yang baik, sebagian besar $(57,1 \%)$ patuh melakukan diet asam urat dan dari 11 responden yang memiliki dukungan keluarga tidak baik, sebagian kecil $(7,1 \%)$ tidak patuh melakukan diet asam urat. Hasil penelitian ini sejalan dengan penelitian yang dilakukan oleh Lestari (2011) bahwa semakin bertambah dukungan keluarga maka semakin tinggi kepatuhan diet pasien. Penelitian ini juga sejalan dengan penelitian yang dilakukan oleh Nurhidayati (2011) bahwa semakin baik dukungan keluarga yang di dapat maka kepatuhan diet semakin tinggi.

Niven (2008) mengatakan bahwa pendidikan dapat meningkatkan kepatuhan, dan memahami faktor-faktor yang berhubungan dengan penyakit serta menggunakan pengetahuan tentang kesehatan untuk menjaga kesehatan dirinya. Penderita yang mempunyi penyakit asam urat yang lama akan mengalami kebosanan dalam melakukan diet, dengan demikian keluarga sangat berperan penting untuk memotivasi anggota keluarganya yang sedang sakit. Dukungan tersebut dapat berbentuk dengan pemberian informasi. Informasi yang dibutuhkan oleh penderita yaitu berupa pemaparan tentang makananmakanan yang perlu dihindari penderita asam urat
(Setiadi, 2008 dalam Amalia, 2017). Dukungan yang lain bisa dalam bentuk dukungan penilaian dan emosional berupa penghargaan positif berupa perhatian dan pujian pada saat penderita melakukan diet dengan tepat, hal tersebut dapat memotivasi penderita untuk tetap rutin menjalankan program diet (Friedman, 2010).

\section{SIMPULAN DAN SARAN}

1. Simpulan

a. Penderita asam urat di posyandu lansia wilayah kerja Puskesmas Wonokromo Surabaya sebagian besar memiliki dukungan keluarga yang baik.

b. Penderita asam urat di posyandu lansia wilayah kerja Puskesmas Wonokromo Surabaya sebagian besar patuh pada diet asam urat

c. Dukungan keluarga berhubungan dengan kepatuhan diet pada penderita asam urat di Posyandu Lansia wilayah kerja Puskesmas Wonokromo Surabaya

2. Saran

a. Bagi masyarakat

Keluarga tetap memberikan dukungan keluarga pada penderita asam urat meskipun bekerja, terutama dukungan emosional, karena adanya dukungan emosional pada penderita asam urat dapat menjadikan harga diri lansia tinggi di dalam keluarga.

b. Bagi tempat penelitian

Meningkatkan program pendidikan kesehatan mengenai pentingnya diet dan pemahaman tentang diet kepada penderita asam urat dan keluarganya. Pendidikan kesehatan ini dilakukan dalam upaya meningkatkan pengetahuan penderita dan keluarga mengenai diet asam urat dan halhal yang berhubungan dengan pengelolaan penyakit asam urat sehingga penderita asam urat lebih patuh terhadap diet yang telah dianjurkan oleh petugas kesehatan.

\section{DAFTAR PUSTAKA}

Achjar, Ayu Henny. K. 2010. Asuhan Keperawatan Keluarga. Jakarta: CV Sagung Seto. 
Agromedia, Redaksi. 2009. Solusi Sehat Mengatasi Asam Urat dan Rematik. Jakarta Selatan: PT Agromedia Pustaka.

Agromedia. 2009. Solusi Sehat Mengatasi Asam Urat \& Rematik. Jakarta: PT Agromedia Pustaka.

Alvin, Aaltje. E, Widhi. 2016. Hubungan Kadar Asam Urat dengan Status Gizi pada Remaja di Kecamatan Bolangitang Barat Kabupaten Bolaang Mongondow Utara. Jurnal e-Biomedik (eBm). Volume 4. No.2. Juli-Desember 2016. Diakses 28 November 2017.

Andreas, L.K., M. Astawan, 2008. Khasiat warna-warni makanan. Jakarta : PT Gramedia Pustaka Utama.

Andry, Saryono, Arif. 2009. Analisis FaktorFaktor Yang Mempengaruhi Kadar Asam Urat Pada Pekerja Kantor di Desa Karang Turi Kecamatan Bumiayu Kabupaten Brebes. Jurnal Keperawatan Soedirman. Volume 4. No. 1. Tahun $2009 . \quad$ Diakses dari http://www.googlescholar.com pada tanggal 20 Oktober 2017.

Arikunto, S. (2013). Prosedur Penelitian: Suatu Pendekatan Praktik. Jakarta: Rineka Cipta

Ayuning Dewi. F. 2014. Pola Makan Lansia Penderita Asam Urat Di Posyandu Lansia Kelurahan Wonokromo Surabaya. Jurnal Ilmiah Kesehatan. Volume 7. No. 12. Tahun 2014. Diakses dari http://www.googlescholar.com pada tanggal 17 januari 2018.

Azwar, Saifudin. (2010). Sikap Manusia Teori Dan Pengukurannya. Yogyakarta, Pustaka Pelajar

Dewi, Sofia. R. 2014. Buku Ajar Keperawatan Gerontik. Yogyakarta: CV Budi Utama.

Friedman, Marilyn. M. 2010. Buku Keperawatan Keluarga. Jakarta: EGC.

Harnilawati. 2013. Konsep dan Proses Keperawatan Keluarga. Sulawesi Selatan: Pustaka As Salam.
Hartono, Andry. 2012. Terapi Gizi dan Diet Rumah Sakit. Jakarta: EGC.

Helmi, Noor. Z. 2012. Buku Ajar Gangguan Muskuloskeletal. Jakarta: Salemba Medika.

Kemenkes, R.I. 2013. Riset Kesehatan Dasar Tahun 2013: Kementrian Kesehatan Republik Indonesia.

Kurnia, Dewi. 2009. Solusi Tepat Berantas Asma Urat. Yogyakarta: Cemerlang Publishing.

Maryam. S. 2009. Mengenal Usia Lanjut dan Perawatannya. Jakarta: Salemba Medika.

Niven Neil. 2008. Psikologi Kesehatan Pengantar untuk Perawat \& Profesional Kesehatan Lain. Jakarta: EGC.

Noor, Zairin. H. 2012. Buku Ajar Gangguan Muskuloskeletal. Jakarta: Salemba Medika.

Noorkasiani, Tamher. S. 2009. Kesehatan usia lanjut dengan pendekatan Asuhan Keperawatan. Jakarta: Salemba Medika.

Notoatmodjo, S. 2007. Promosi Kesehatan dan Ilmu Perilaku. Jakarta: Rineka Cipta.

Notoatmodjo, S. 2012. Metodologi Penelitian Kesehatan. Jakarta: Rineka Cipta.

Noviyanti. 2015. Hidup Sehat tanpa Asam Urat. Yogyakarta: Notebook (Perpustakaan Nasional RI).

Nursalam. 2013. Metodologi Penelitian Ilmu Keperawatan. Jakarta: Salemba Medika

Nugroho, Wahjudi. 2008. Keperawatan Gerontik \& Geriatrik, Ed.3. Jakarta: EGC

Paulina, Hendro, Vendri. K. 2016. Hubungan Tingkat Stres Dengan Kejadian Gout Artrtitis di Puskesmas Tobelo Kecamatan Tobelo Kabupaten Halmahera Utara. EJurnal Keperawatan (eKp). Volume 4 No. 1. Februari 2016. Diakses dari http://www.googlescholar.com pada tanggal 20 oktober 2017. 
Ramayulis. R, Astuti. T. 2008. Menu dan Resep Untuk Penderita Asam Urat. Jakarta. Penebar Plus.

Setiadi. 2008. Konsep \& Proses Keperawatan Keluarga. Yogyakarta: Graha Ilmu.

Sudiharto. 2007. Asuhan Keperawatan Keluarga dengan Pendekatan

Keperawatan Transkultural. Jakarta: EGC.

Suparyono. 2010. Konsep Kepatuhan. Diakses dari http://www.drsuparyanto.com. pada tanggal 28 oktober 2017. 